\title{
Is the Doctor in? PhD to Professional: Complementary Perspectives in Research Libraries
}

\section{Eleanor Warren}

\author{
University of Leeds \\ e.m.warren@leeds.ac.uk, orcid.org/0000-0002-6386-8531
}

\begin{abstract}
Aim: This paper considers how changes in the research landscape are simultaneously changing the skills needs of library staff, and opening up new opportunities for researchers to pursue careers within libraries. It explores what skills, competencies and knowledge staff with doctoral qualifications can bring to library research support services.

Context: Librarians working in research support areas need different skills to the skills academic librarians have traditionally needed. There is currently a gap in the training which those undertaking professional librarianship qualifications receive, in relation to the skills needed for research roles. Simultaneously, expansion in the numbers of PhD students in the UK in recent years has been accompanied by the professionalisation of researcher skills development, equipping students with transferable skills for careers outside, as well as inside, academia.
\end{abstract}

Methodology: This paper compares the skills' needs of research librarians with the competencies and skills of doctoral graduates, specifically in the UK context (as articulated in the Vitae Researcher Development Framework). It also surveys and discusses the skill-set and qualifications of research support staff employed at three UK research libraries.

Results: Understanding the needs and, importantly, the behaviours, of researchers is integral to the provision of a successful library research support service. Many of the skills which are necessary for library graduates to have, are those that are already identified as essential researcher skills. The peerlevel support offered by library staff with research backgrounds has a role in developing stronger relationships between the library and the academy. 
Key Words: research skills; Researcher Development Framework; library training; research support services

\section{Introduction}

The role of libraries in supporting researchers is changing due to an evolving research environment. Changes in the scholarly communications landscape and in researcher skills development have shifted the focus in many academic libraries, encouraging them to re-think how best to support their institutional research strategy. The challenge is understanding the needs of researchers and ensuring that research support librarians have the right skills to respond to these needs. With these changes, there has also been discussion about education and training for librarianship, and about who and what a librarian is. ${ }^{1}$ This paper explores the skills needs of library staff, and how the roles now needed in research libraries are opening up opportunities for researchers to pursue careers within libraries. In the UK, both developments have emerged out of the changed research landscape, and the publication and implementation of certain national reports in the early years of the twenty-first century. Researcher development training in the UK has led to researchers now possessing many of the skills being suggested as necessary for librarians in research support areas. Furthermore, this could offer a useful framework for the development of librarian training.

The skills developed during doctoral training have practical applications for working in library research support. Similarly, having experience of the doctoral process adds value to the service that library teams provide to researchers. Doctoral graduates are suited to the new roles in scholarly communication and research support, in different, but complementary, ways to those with library and information science qualifications. This is especially significant at a time when many libraries may be looking to demonstrate their value to researchers and to their institution.

\section{Researcher Skills and Experience}

In 2002 a UK government report, entitled 'SET for Success,' was published by Sir Gareth Roberts (Roberts, 2002). Roberts noted that researchers in 
higher education had high quality skills to offer, but that they were often unable to articulate these adequately to non-academic employers. They also lacked certain key transferable skills, for example, in communication and team working (Reeves, 2013, p. 137). Roberts' view was that the PhD should be about developing the person, and that researchers needed to be trained in transferable skills, as well as in research skills (Reeves, 2013, p. 139). Several years after Roberts' recommendations, an independent review of his agenda found that transferable skills courses had become an integral part of the UK's postgraduate research programmes. Nevertheless, there was concern over the sustained future of such developments (Hancock \& Walsh, 2014, p. 41; Hodge, 2010).

Nearly ten years after Roberts' review, the changing demands, and characteristics researchers need to possess, were identified through the development of a national resource: the Researcher Development Framework (RDF) (Reeves, 2013, p. 137; Vitae, 2011). ${ }^{2}$ The RDF, published in 2011, was based upon what researchers themselves identified as important, and this turned out to be more about personal effectiveness, than discipline knowledge and intellectual skills. In particular, researchers indicated that enthusiasm and curiosity were essential for motivation, whilst self-confidence, perseverance, and time management were essential for the creation and success of research outputs. Subject knowledge is significant, but the data on which the RDF was based, suggested it was not knowledge, as such, that mattered most, but rather what one did with it (Reeves, 2013, p. 141). Since the implementation of the RDF, work has been undertaken to evaluate the impact of training and development activities for researchers, in the post-Roberts era, including the 2012 Impact Framework (Bromley \& Metcalfe, 2012).

Expansion in the numbers of PhD students, alongside the professionalisation of researcher skills development, has considerably changed the career destinations of doctoral graduates (Hancock \& Walsh, 2014, p. 37). Importantly, the $\mathrm{RDF}$ also challenged the view that there was only one way to be a researcher and to be successful (Reeves, 2013, p. 143).

We know that doctoral graduates are pursuing careers outside of academic research posts. The purpose and nature of a doctoral degree is changing, to a broader-based training ground for skilled researchers who will be able to function in the modern, dynamic workplace, both inside and outside of 
academia (Bromley, Boran, \& Myddelton, 2007, p. 118). Entry to the academic profession is now just one of many options (Hancock \& Walsh, 2014, p. 43). Almost half of doctoral graduates leave university research in the first three years after their $\mathrm{PhD}$, with three-quarters of this group leaving the academy entirely (McAlpine \& Emmioğlu, 2014, p. 1770). Many are entering researchrelated roles in Higher Education, including in libraries, where they can utilise their research skills and experience (QAA, 2015, p. 4). In 2016, Vitae, the national organisation for researcher development in the UK, published (as part of the series 'What do researchers do?'), 'What do research staff do next?' (Vitae, 2016). This aimed to identify what careers European researchers pursue beyond academia. It reports on the results of a survey of research staff from European universities or research institutes, who have moved into other occupations. The majority of respondents were still working in the research system in some way, and making use of their research background: over a quarter were found to be working within higher education in professional roles, such as research and innovation, public engagement, researcher development, and as librarians, or career advisors. Many still maintain their connection with research through continued collaborations or part-time teaching. The project revealed the range of employment opportunities open to research staff beyond Higher Education research (Vitae, 2016, pp. 4, 20).

The survey found that there is commonality in the key transferable competencies reported as needed for success in these new roles. These included: communication, critical thinking, problem solving, team work and collaboration, independent working, project management, adaptability, time management, and networking (Vitae, 2016, pp. 4, 20). These skills are precisely those which are included as descriptors in the RDF (see Table 1). There is strong evidence from Vitae that researchers are still making critical contributions in sustaining the research system in their roles outside research positions. Many of these roles are newly created as a result of the increase in the provision of structured doctoral programmes, and the increased complexity of research and innovation activity. The experience that researchers bring to these roles is highly appropriate and valuable (Vitae, 2016, p. 45).

The benefit of doctoral degrees is therefore not only in specialist subject knowledge. It is the skills and experiences developed in the process of acquiring, critiquing and creating new specialist subject knowledge which is of value. Bromley and Metcalfe (2012), on behalf of the Impact and Evaluation 
Table 1: Comparison of terminology for transferable competencies identified in Vitae survey (2016), with Research Development Framework descriptors (Vitae, 2011).

\begin{tabular}{ll}
\hline $\begin{array}{l}\text { Competencies identified by researchers } \\
\text { working outside academia (Vitae, 2016) }\end{array}$ & $\begin{array}{l}\text { Researcher Development } \\
\text { Framework descriptors (Vitae, 2011) }\end{array}$ \\
\hline Communication & Communication methods/media \\
Critical thinking & Critical thinking \\
Problem solving & Problem solving \\
Teamwork and collaboration & Team working/collaboration \\
Independent working & Responsibility/preparation \\
Project management & Project planning and delivery \\
Adaptability & Responsiveness to change \\
Time management & Time management \\
Networking & Networking/collegiality \\
\hline
\end{tabular}

Group (those involved in training doctoral candidates), have recognised and reported on this. ${ }^{3}$

Therefore, how do the transferable skills and research experience of doctoral graduates translate to working in research libraries, and are these skills needed in that context? I suggest that not only are researchers' skills relevant, but that having a research background enables library staff to engage effectively with researchers, and to offer them a level of peer support. This gives researchers confidence that the services being offered by the library have value to them.

\section{Library Skills and Engaging with the Research Community}

Librarians need certain skills in order to fulfil researchers' needs, and those of their institutional research strategies. Understanding the needs and, importantly, the behaviours, of researchers is integral to the provision of a successful library research service. The 2011 report by the Research Information Network and Research Libraries UK, identified the key characteristics of library provision required to support research in successful UK universities. There was an emphasis placed upon the personal, professional and career development of researchers, driven by the RDF (RIN \& RLUK, 2011). As a result, new roles have been created in libraries, and this is leading to a commensurate need for staff with new knowledge and skills. 
Several studies have explored the changing training needs and skills of academic librarians. An RLUK survey reported that the skill areas library postgraduates have a good understanding of, are in information-related activities, such as information discovery, including knowledge of information resources, information management, citation and referencing, and collections management. But librarians have to work hard to demonstrate that they can add value to researchers' literature searching (Auckland, 2012, pp. $2,19,66)$. It has been acknowledged that librarians need to adapt and play a greater part in the research process. They must understand, support, and also participate in, all aspects of the research lifecycle (Jaguszewski \& Williams, 2013, p. 4; Sewell \& Kingsley, 2016). However, there is a small, but growing body of evidence in the UK that those with Library and Information Science qualifications, working in research-related roles in libraries, do not feel that their qualifications are particularly relevant to their work (Kingsley, 2017a; Sewell, 2017). If professional library training is not equipping people appropriately, or it was undertaken too long ago to now be relevant, what are the skills needed that are missing? Are there other groups of people who already have these skills? And if so, 'will staff with the appropriate skills be considered [library] professionals, or will they remain outsiders?' (Shipp, 2016, p. 284).

Although libraries are changing, there are still worrying trends in researchers' perceptions of their role. The 2016 report from CIBER found that 'libraries seem to have lost all their visibility. Lots of ECRs have not gone to the library for years [...] Libraries appear to have little to offer to the big new wave of researchers, so down the line there have to be worries for their long term future as resources for postdocs' (CIBER, 2016, p. 12). ${ }^{4}$

One of the ways in which librarians are being encouraged to engage with their research community is by becoming researchers and authors themselves. CILIP suggest that it is easier to engage with researchers if you are able to empathise with them, and to show you have struggled with similar issues (Bent, 2016). Similarly, Danny Kingsley at the University of Cambridge, has suggested that one of the solutions to librarians engaging with researchers, especially around scholarly communication, is to 'shift from managing academic literature to participating in the generation of it' (Kingsley, 2016a, 2017b). Activities such as publishing, peer reviewing, and presenting at conferences are more traditionally seen as academic work, rather than the work of librarians. However, we should acknowledge that library staff are 
already undertaking research and pursuing these activities, especially in the areas of scholarly communication, and student and researcher development (Kingsley, 2016a).

After several decades in which librarians have strived to establish librarianship as a distinct profession, it appears that the boundaries between researchers and research librarians are blurring. I suggest that this should be more formally recognised within the library profession, in relation to training and recruitment. There have already been arguments made for a team approach and the emerging need for a new type of library workforce, with members drawn from different backgrounds, who are able to bring a range of different skills to their roles (Jaguszewski \& Williams, 2013, pp. 13-14; Schmidt, Calarco, Kuchma, \& Shearer, 2016, pp. 2, 6; Sewell \& Kingsley, 2016). Library teams need to be interdisciplinary in order to benefit interdisciplinary research teams (Jaguszewski \& Williams, 2013, p. 4), and library science is just one discipline. Researchers need library professionals who understand disciplinary differences and who are responsive to these needs (Jaguszewski \& Williams, 2013, p. 4).

If it is the case, as reported by RLUK, that 'most researchers are unaware of what professional library staff have to offer and are not convinced of their relevance or likely value' (RLUK, n.d.), then the value of doctoral graduates in professional library roles seems to have potential benefit beyond what they can also offer in terms of transferable research skills. Researchers who have moved into careers in libraries already have shared experiences with the research community, and can bring with them an understanding of multiand inter-disciplinary research, and of scholarly communications. RLUK also reported that better links with researchers and academic departments help the library to position itself in a changing environment (RIN \& RLUK, 2011, p. 20). Researchers, whether they are freshly-minted doctoral graduates, or have worked in research for some years, tend to have built up and maintain networks of other researchers. Therefore, as librarians, they can act as advocates for the library and its services.

Increasingly, the skills and competencies being identified as necessary for successful librarians, particularly in the areas of research support and scholarly communication, ${ }^{5}$ are those which have already been articulated for researchers and research developers in the RDF. Candy Davis has argued that 'the qualities and competencies called for in the 21st century 
librarian $[\ldots]$ are flexibility, vision, the ability to think critically yet synthetically, to form partnerships, to collaborate, to continue learning and to teach others' (Davis, 2008, p. 77). In a recent issue of SCONUL Focus, several educators from library schools in the UK and the Republic of Ireland were interviewed about the skills necessary for successful librarians and information professionals. Their answers included: a passion for the acquisition and sharing of knowledge, a love for scholarship, and an interest in research, communication and people skills, an ability to network, ease with the developing technological and digital environment, an ability to work under pressure, problem-solving, and teaching skills. They should also be innovators and project managers, be creative, innovative, and seek solutions (Robinson et al., 2016). It has also been suggested that there is a need for leadership skills in those occupying all library roles, not just those within positional leadership (Jaguszewski \& Williams, 2013, p. 14). Similarly, Marie O'Neill reflected that he was already looking at the librarian of the future, at the Library Futures Symposium (May 2016): 'they were scholars, publishers, leaders, managers, public speakers, collaborators, event and PR managers, project managers, and IT, design and marketing savvy' (O’Neill, 2016).

The RDF descriptors correspond accordingly to these skills (Table 2). In short, the skills needs of librarians are the same skills which researchers are being trained in, and have developed, particularly since the publication of the RDF. Researchers are therefore potentially well suited, and skilled, to work

Table 2: Comparison of skills identified as needed for librarians, with the Researcher Development Framework descriptors (Vitae, 2011).

\begin{tabular}{ll}
\hline Skills needs for librarians & $\begin{array}{l}\text { Researcher Development Framework } \\
\text { descriptors (Vitae, 2011) }\end{array}$ \\
\hline Passion for research and scholarship & $\begin{array}{l}\text { Enthusiasm/commitment to research } \\
\text { Project management }\end{array}$ \\
Project planning and delivery \\
Commution & Innovation \\
Critical thinking & Communication methods/media \\
Problem solving & Critical thinking \\
Ease with developing digital environment & Problem solving \\
Creativity and ability to seek solutions & Responsiveness to change/research methods \\
Teaching & Inquiring mind/intellectual risk \\
Leadership & Teaching \\
\hline
\end{tabular}


as librarians. Furthermore, they have the potential to both embrace, and significantly, initiate the change which is now prevalent, and needed, within research libraries.

The broader question is what constitutes being qualified for a librarian role, and how library recruitment can bring in people already trained with the skills and experience which are necessary for the library workforce of the future. In the US, the CLIR Postdoctoral Fellowship Program has been offering $\mathrm{PhD}$ graduates the chance to develop careers in libraries since 2004. The programme enables fellows to develop connections between libraries, education, and research, and recognises the specialist expertise that fellows can provide to their host institutions' collections, scholarly information behaviours, and teaching and learning practices. ${ }^{6}$ However, such opportunities and routes into library careers have not yet developed in the same way in the UK.

Sarah Pittaway, at UKSG Forum 2016, addressed the issue of current library qualifications, in her paper 'When is a librarian not a librarian?' She suggested that recruiters need to consider those already working in the sector without library qualifications, and the impact on staff recruitment if employers continue to require a library qualification as essential to these roles (Pittaway, 2016). Drabinski argues that in order for some people to be professionals, other people must be non-professionals and excluded from the circle of privilege that professionalization affords. Indeed, professional discourse might be $[\ldots]$ enhanced by broadening the range of voices and experiences invited to speak' (Drabinski, 2016, pp. 612-13). As one commenter on the blog 'Why All the Fuss over PhD Academic Librarians,' summed up, 'highly-skilled researchers with a passion for library service are librarians, regardless of their advanced degrees' (Wilkinson, 2011). This seems to be the case now, more than ever.

\section{White Rose University Libraries}

In response to the 2011 report by the Research Information Network and Research Libraries UK, identifying the need for change in library provision, the University of Leeds, like many academic research libraries in the UK, moved away from the academic liaison librarian model, in favour of the 'functional-specialist approach. ${ }^{7}$ A Research Support Team and Research 
Data Team were formed in 2014 from existing library staff, who have developed and diversified their skills to meet the broader support needs of the research community and the University's research strategy.

The RLUK report does not specifically mention whether the need for changes to libraries and library roles, should or might include a change to the library workforce and recruitment, and the employment of people with different skills and experiences. Since the re-structure of the library at the University of Leeds, new staff from different educational backgrounds have joined the teams of existing librarians. Whilst perhaps not yet part of a conscious recruitment process, are libraries finding that candidates with research backgrounds are fulfilling these new needs?

In October 2016 the Office of Scholarly Communication at the University of Cambridge conducted a survey into the educational backgrounds of people working in scholarly communication and associated areas, with the hope of identifying the suitability of Library and Information Science qualifications for these roles (Sewell, 2016). One initial finding indicated that there are people with many different backgrounds working in these roles, including a significant number of people coming from outside the library sector (Sewell, 2016). The survey also revealed that those respondents without Library and Information Science (LIS) qualifications, but with other postgraduate degrees (including PhDs), felt that 'what they learnt during their studies had practical applications in their work in scholarly communication.' This was a larger percentage than those who had studied LIS at either undergraduate or postgraduate level (Sewell, 2017).

To investigate further, a small scale survey was conducted, in May 2017, of the library and archive staff working in research-related roles at the White Rose Universities of Leeds, Sheffield and York. The university libraries at Sheffield and York both have specialist research support service teams, similar to that at Leeds. For the purpose of the survey the role of library research support was defined as anyone working in specialist areas which support researchers at any stage of their research lifecycle. This includes library staff working in scholarly communication, research data, researcher skills development, and special collections and archives. A particular focus of the survey was upon the skills and attributes articulated in the RDF. The questionnaire and the corresponding results for this survey are available at the Harvard Dataverse: https://doi.org/10.7910/DVN/SC4BZY. 
In total, there were thirty-nine responses to the survey. This is a small sample, however, it is a representative proportion of the total population of those who were targeted. Two-thirds of those working in scholarly communications/ research services (i.e. not archives or special collections) at the three libraries responded to the survey. Findings reflect the recent developments of specific research support roles in academic libraries, with eighty-seven percent of respondents having been in their current role for less than five years. For fortysix percent of respondents their current role is their first role within the sector, suggesting that there has recently been an influx of either early-career librarians, or people from outside libraries and archives, entering the workforce.

Results show that the White Rose Libraries currently employ staff from a range of different educational and professional backgrounds, including doctoral graduates. Since completing their education, just less than half of respondents (44\%) have worked exclusively within libraries or archives, whilst fifty-five percent have previously worked outside the sector. The majority of respondents (59\%) hold a LIS or Archive qualification. ${ }^{8}$ However, only nine percent of these respondents ( 2 out of 23 ) felt that their qualification had fully equipped them for their current role, and twenty-seven percent (6 out of 23) felt it had not equipped them; with the remaining sixty-four percent (14 out of 23) indicating that their LIS or Archive qualification had partly equipped them for their current role (see Figure 1). Those who commented on which skills and experience from their qualification are relevant to their current role focussed on areas regarding information management, such as information searching, organisation, information cultures, cataloguing, and metadata, as well as a limited amount about the concept of Open Access. These are skills which those with library science qualifications are more likely to have, and which researchers may not.

Whilst the majority do have professional LIS or Archive qualifications, a high proportion $(41 \%)$ of respondents working in research support roles do not have these formal qualifications. Of these, seventy-five percent (12 out of 16) have a postgraduate qualification in another subject, ${ }^{9}$ and fifty percent of these are at doctoral level (6 out of 12). The total number of respondents with PhDs was seven, because one respondent has a PhD and a LIS/Archive qualification. ${ }^{10}$ Although it is a small sample, two out of seven $(29 \%)$ respondents with $\mathrm{PhDs}$ felt that their doctoral degree had fully equipped them for their current role, and only one out of seven (14\%) felt it had not equipped them at all. The comparisons between the results for those with LIS qualifications and those with PhDs are shown in Figure 1. 
Fig. 1: Results from survey of White Rose Library staff. Question: "Do you feel that your qualification equipped you for your current role working with researchers?."

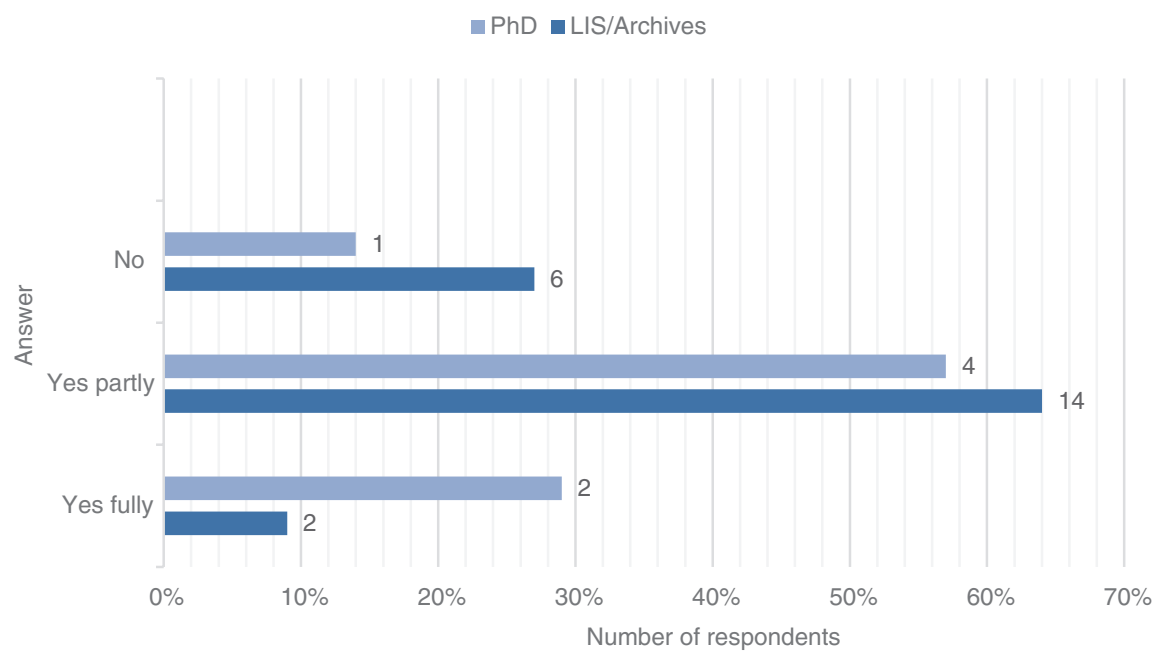

Those respondents with PhDs commented that their training had given them transferable skills such as critical analysis of sources, creativity, information searching, project management, and presentation skills. In addition to this, there was a strong indication from respondents that their doctoral training and experience as a researcher enabled them to engage with the research community in a direct way. They commented that they were able to understand, first-hand, the research lifecycle, the pressures of academia, and the different tasks and roles which academic staff and postgraduate researchers undertake - in short, what it is that researchers do all day ${ }^{11}$ and that this was beneficial to their current roles. One aspect which arose, is the ability to talk to researchers in their own language. Research language and terminology has been briefly discussed in this context before (Kingsley, 2016a, 2017b), but it is important to consider that the language of the library and librarians, may not translate effectively to the research community. It is necessary to recognise that language is discipline specific, and is therefore potentially as diverse as the subjects in which researchers specialise (Kingsley, 2016a).

All respondents were asked whether they have actively undertaken research or participated in the scholarly publication process themselves. 
The highest percentage ( $46 \%$ ) have done so by authoring publications, and just less $(44 \%)$ have presented research at academic conferences. This indicates that research support staff are already undertaking academic activities which, as has been suggested, will help them to engage with the research community.

To determine whether the skills and attributes articulated in the RDF are those which might be needed for research-related library roles, the survey of White Rose library staff listed a number of the current RDF descriptors. ${ }^{12}$ Respondents were asked to assess whether a particular descriptor was part of their qualification or training, and whether they thought it was relevant to their current role. Those with LIS/Archive qualifications and those with PhDs were presented with the same list. Figure 2 shows

Fig. 2: Results from survey of White Rose Library staff. Question: "Indicate if the following knowledge, skills or attributes were part of your training and development."

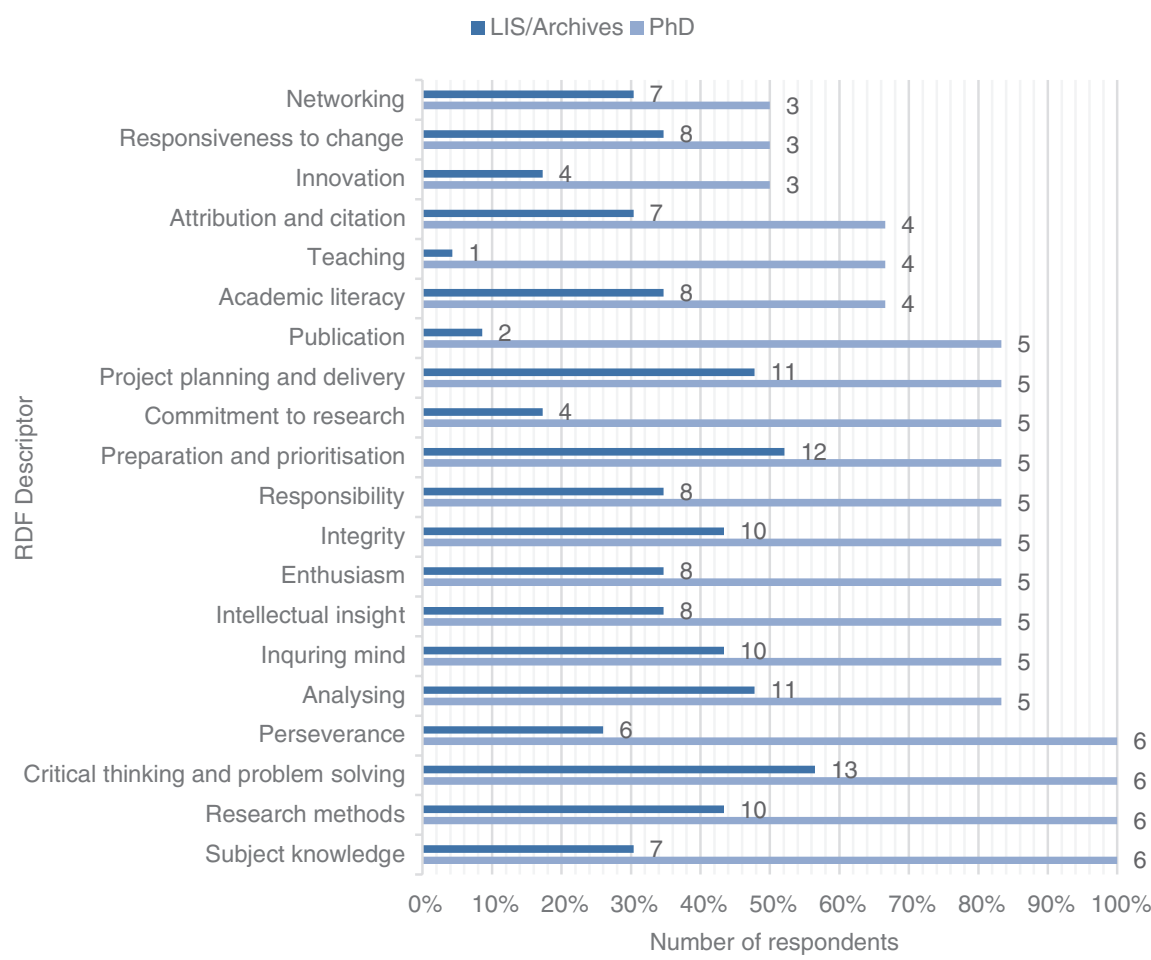


the RDF descriptors for which a higher percentage of those with PhDs, than those with LIS qualifications, indicated that the descriptor was part of their qualification training. However, the results in Figure 3 suggest that there may be potential gaps in the qualification and training for PhDs, in the areas of income funding and generation, public engagement, and IPR and copyright. For some of the descriptors a higher percentage of those with LIS or Archive qualifications indicated that the descriptor was part of their training (see Figure 3). These were primarily those descriptors which related to skills in information-related activities, such as information seeking and management. This result is not unexpected. However, higher percentages of those with LIS/Archive qualifications, than those with PhDs, indicated overall that the descriptors listed were relevant to their current roles (Figure 4). This may have to do with the specific roles that those individuals with doctoral degrees are working in, or it might be that doctoral graduates are still unable to adequately recognise how they use the skills and attributes from their doctoral training, in their non-academic roles. The survey results on such a small population sample cannot indicate too much more at present. However, what is significant is that library staff with LIS qualifications do think that the RDF skills and attributes are relevant to their roles in research support, yet, in the main, they have not been trained

Fig. 3: Results from survey of White Rose Library staff. Question: "Indicate if the following knowledge, skills or attributes were part of your training and development."

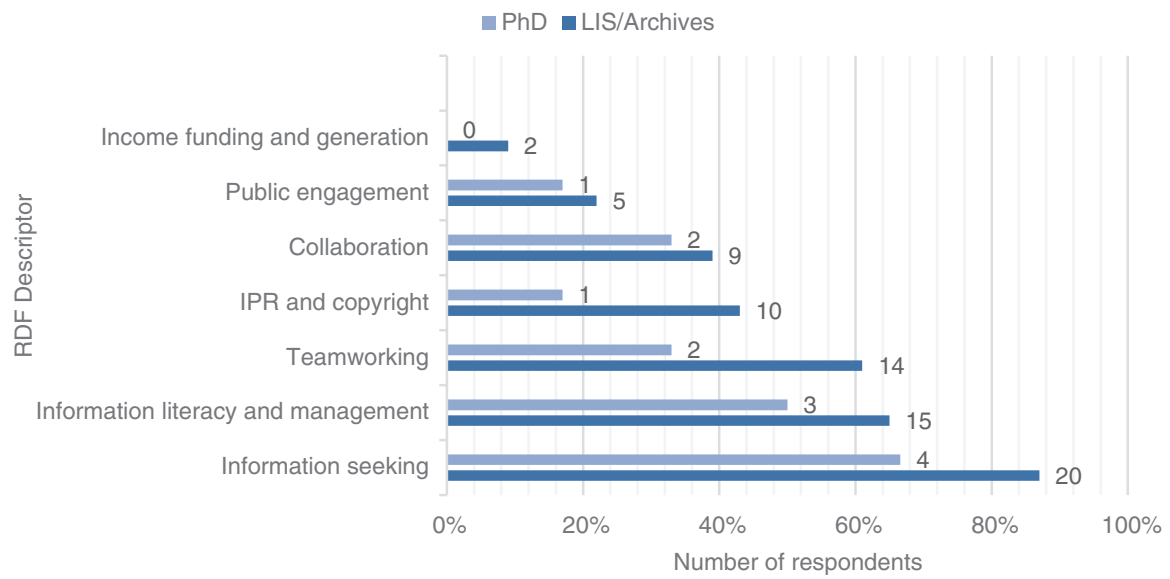


Fig. 4: Results from survey of White Rose Library staff. Question: "Indicate if the following knowledge, skills or attributes are relevant to your current role supporting researchers."

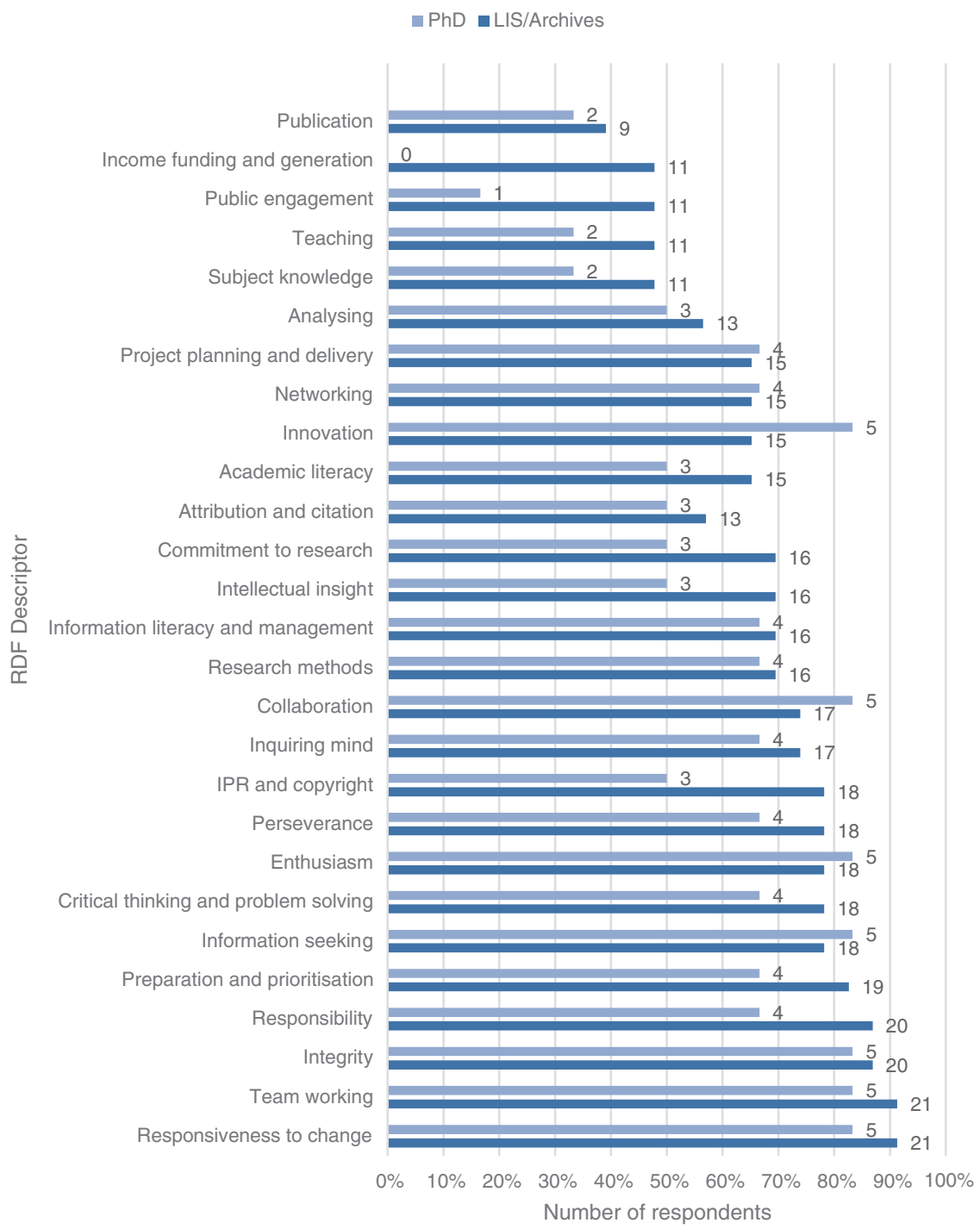

in these areas. Utilising the RDF domains and descriptors, therefore, could provide a framework in future evaluation of librarian skills and in developments to library qualification training. 


\section{Conclusion}

The results of this survey show that the majority of respondents come from a library or archive background, but there is a high proportion who have come from other educational or professional backgrounds. Many of the skills now being suggested within the library community as useful, or potentially necessary, for library graduates to have (Kingsley, 2017a), are those that have already been identified as essential researcher skills, articulated in the RDF. The wider issue is, therefore, what constitutes being qualified for a librarian role, and how library recruitment can bring in people already trained with the skills and experiences which are necessary for the library workforce of the future. Simultaneously, librarianship training and qualifications, if they are to continue in the UK, must be developed, so that libraries can recruit people with the right skills, competencies and attributes for the jobs at hand. The changes in research libraries are inseparable from the training and career developments of doctoral researchers. This is a question of diversification, training and investing in people with valuable skills, for the future of research libraries. Now more than ever, it must be a case of staffing our libraries with the best individuals who keep them strong and relevant to the community. ${ }^{13}$

\section{Acknowledgement}

With thanks to Danny Kingsley and Claire Sewell from the Office of Scholarly Communication at the University of Cambridge, for discussions prior to the presentation of this paper at LIBER Conference 2017.

\section{References}

Alpay, E., \& Walsh, E. (2008). A skills perception inventory for evaluating postgraduate transferable skills development. Assessment $\mathcal{E}$ Evaluation in Higher Education, 33(6), 581-598. https://doi.org/10.1080/02602930701772804.

Auckland, M. (2012). Re-skilling for research: An investigation into the role and skills of subject and liaison librarians required to effectively support the evolving needs of researchers. Retrieved June 29, 2017, from http:/ / www.rluk.ac.uk/wp-content/ uploads/2014/02/RLUK-Re-skilling.pdf. 
Bent, M.J. (2016, March 21). 6 tips for librarians to engage with their research community [Blog post]. CILIP. Retrieved December 21, 2016, from https://archive.cilip.org.uk/ blog/6-tips-librarians-engage-their-research-community.

Bray, R., \& Boon, S. (2011). Towards a framework for research career development: An evaluation of the UK's Vitae Researcher Development Framework. International Journal for Researcher Development, 2(2), 99-116. https://doi. org/10.1108/17597511111212709.

Bromley, T., \& Metcalfe, J. (2012). The impact framework 2012: Revisiting the rugby team impact framework. Cambridge: Careers Research and Advisory Centre Limited. Retrieved from the Vitae website https://www.vitae.ac.uk/vitae-publications/ reports/ieg-report-2012.pdf.

Bromley, A.P., Boran, J.R., \& Myddelton, W.A. (2007). Investigating the baseline skills of research students using a competency-based self-assessment method. Active Learning in Higher Education, 8(2), 117-137. https://doi. org $/ 10.1177 / 1469787407077992$.

CIBER (2016). Early career researchers: The harbingers of change? Publishing Research Consortium. Retrieved June 9, 2017, from http://publishingresearchconsortium. com/index.php/136-prc-projects/research-reports/early-career-researchers-year-one.

Davis, C. (2008). Librarianship in the $21^{\text {st }}$ century - crisis or transformation? Public Library Quarterly, 27(1), 57-82. https://doi.org/10.1080/01616840802122401.

Drabinski, E. (2016). Valuing professionalism: Discourse as professional practice. Library Trends, 64(3), 604-614. https://doi.org/10.1353/lib.2016.0005.

Ferguson, J. (2016). Additional degree required? Advanced subject knowledge and academic librarianship. portal: Libraries and the Academy, 16(4), 721-736. https://doi. org/10.1353/pla.2016.0049.

Hancock, S., \& Walsh, E. (2014). Beyond knowledge and skills: Rethinking the development of professional identity during the stem doctorate. Studies in Higher Education, 41(1), 37-50. https://doi.org/10.1080/03075079.2014.915301.

Hodge, A. (2010). Review of progress in implementing the recommendations of Sir Gareth Roberts, regarding employability and career development of PhD students and research staff. Research Councils UK. Retrieved June 22, 2017, from http://www.rcuk.ac.uk/ documents/skills/IndependentReviewHodge-pdf/.

Jaguszewski, J.M., \& Williams, K. (2013). New roles for new times: Transforming liaison roles in research libraries. Washington: Association of Research Libraries. Retrieved June 14, 2017, from http://www.arl.org/component/content/article/6/2893.

Kingsley, D. (2016a, March 11). The value of embracing unknown unknowns [Blog post]. Unlocking Research. Retrieved April 10, 2017, from https://unlockingresearch. blog.lib.cam.ac.uk/?p=594. 
Kingsley, D. (2016b, February 1). What does a researcher do all day? [Blog post] Unlocking Research. Retrieved June 19, 2017, from https://unlockingresearch.blog.lib. cam.ac.uk/?p=515.

Kingsley, D. (2017a, April 12). Shifting sands: notes from UKSG2017 workshop on skills [Blog post]. Unlocking research. Retrieved June 19, 2017, from https:// unlockingresearch.blog.lib.cam.ac.uk/?p=1417.

Kingsley, D. (2017b, March 30). "Become part of the research process" - observations from RLUK 2017 [Blog post]. Unlocking Research. Retrieved June 16, 2017, from https://unlockingresearch.blog.lib.cam.ac.uk/?p=1384.

McAlpine, L., \& Emmioğlu, E. (2014). Navigating careers: perceptions of sciences doctoral students, post-PhD researchers and pre-tenure academics. Studies in Higher Education, 40(10), 1770-1785. https://doi.org/10.1080/03075079.2014.914908.

O'Neill, M. (2016, May 23). The Library of the Future, the Future of the Library [Blog post]. Libfocus. Retrieved June 9, 2017, from http://www.libfocus.com/2016/05/ the-library-of-future-future-of-library.html.

Pittaway, S. (2016). When is a librarian not a librarian? Retrieved from the UKSG Forum: London 2016 website: https:/ / www.uksg.org/event/forum2016.

QAA (2015). Characteristics statement: doctoral degree, UK quality code for higher education part A: Setting and maintaining academic standards. The Quality Assurance Agency for Higher Education. Retrieved August 3, 2017, from http://www.qaa.ac.uk/en/ Publications/Documents/Doctoral-Degree-Characteristics-15.pdf.

Reeves, J. (2013). Matching the characteristics of researchers with the demands of $21^{\text {st }}$ century research. In M. Kompf \& P. M. Denicolo (Eds.), Critical issues in higher education (Vol. 8) (pp. 137-145). Rotterdam: Sense Publishers.

RIN \& RLUK (2011). The value of libraries for research and researchers: A RIN and RLUK report. London: Research Information Network. Retrieved February 7, 2017, from http://www.rin.ac.uk/our-work/using-and-accessing-information-resources/ value-libraries-research-and-researchers.

RLUK (n.d.). Supporting researchers [Blog post]. Research Libraries UK. Retrieved December 21, 2016 from http://www.rluk.ac.uk/strategicactivity/strategic-strands/ redefining-research-library-model/foundations/supporting-researchers/.

Roberts, G. (2002). SET for success: The supply of people with science, technology, engineering and mathematics skills. The report of Sir Gareth Roberts' Review. London: HM Treasury. Retrieved August 2, 2017 from http:/ / webarchive.nationalarchives.gov. uk/+/http:/www.hm-treasury.gov.uk/d/robertsreview introch1.pdf.

Robinson, L., O'Neill, M., Simon, A., Bates, J., Shankar, K., Matthews, P., \& Reid, P. (2016). Developing the professionals of the future: Views from experts in 'library schools.' SCONUL Focus, 67, 5-16. Retrieved August 16, 2017, from https://www. sconul.ac.uk/sites/default/files/documents/2 18.pdf. 
Schmidt, B., Calarco, P., Kuchma, I., \& Shearer, K. (2016). Time to adopt: Librarians' new skills and competency profiles. In F. Loizides \& B. Schmidt (Eds.), Positioning and power in academic publishing: Players, agents and agendas (pp. 1-8). Amsterdam: IOS Press Ebooks. https://doi.org/10.3233/978-1-61499-649-1-1.

Seminelli, H. (2016). Librarian as professional. The Serials Librarian, 71(1), 63-69. https://doi.org/10.1080/0361526X.2016.1168667.

Sewell, C. (2016, October 27). Are academic librarians getting the training they need? [Blog post]. Unlocking research. Retrieved June 19, 2017, from https:// unlockingresearch.blog.lib.cam.ac.uk/?p=995.

Sewell, C. (2017, March 9). Where did they come from? Educational background of people in scholarly communication [Blog post]. Unlocking research. Retrieved June 19, 2017, from https://unlockingresearch.blog.lib.cam.ac.uk/?p=1313.

Sewell, C., \& Kingsley, D. (2016, November 29). Changing roles and changing needs for academic librarians [Blog post]. Unlocking research. Retrieved June 14, 2017, from https://unlockingresearch.blog.lib.cam.ac.uk/?p=1189.

Sewell, S., \& Kingsley, D. (2017, April 28). Developing the 21st century academic librarian: The research support ambassador programme. New Review of Academic Librarianship 23(2-3), 148-158. https:/ / doi.org/10.1080/13614533.2017.1323766.

Shipp, J.N. (2016). Do I really need specialist qualifications to work as a professional in a gallery, library, archive or museum? The Australian Library Journal, 65(4), 280-287. https://doi.org/10.1080/00049670.2016.1233604.

Steven, B. (2011, April 16). 14 thoughts on "Why all the fuss over PhD academic librarians" [Blog comment]. ACRLog. Retrieved from http://acrlog.org/2011/04/13/ why-all-the-fuss-over-phd-academic-librarians/.

Vitae. (2011). Researcher development framework. Retrieved August 2, 2017, from https://www.vitae.ac.uk/rdf.

Vitae. (2016). What do research staff do next? Cambridge: The Careers Research and Advisory Centre (CRAC) Limited. Retrieved August 2, 2017, from https:/ / www. vitae.ac.uk/vitae-publications/reports/vitae-what-do-research-staff-do-next-2016. pdf.

Warren, E. (2017, July 28). Sustainable knowledge and the power of libraries - LIBER Annual Conference, University of Patras, July 2017 [Blog post]. Leeds University library. Retrieved July 28, 2017, from https://leedsunilibrary.wordpress.com/2017/07/28/ sustainable-knowledge-and-the-power-of-libraries-liber-annual-conferenceuniversity-of-patras-july-2017/.

Wilkinson, L. (2011, April 13). 14 thoughts on "Why all the fuss over PhD academic librarians" [Blog comment]. ACRLog. Retrieved from http://acrlog.org/2011/04/13/ why-all-the-fuss-over-phd-academic-librarians/. 


\title{
Notes
}

\begin{abstract}
${ }^{1}$ Seminelli (2016) is worried about the downgrading of library position requirements, in the US context. Also see Davis (2008); Drabinski (2016); Ferguson (2016); Sewell and Kingsley (2017). The discussion of changing skills needs for librarians, and what people without qualifications in library and information science can offer to research libraries as part of the workforce, has gained some traction in the UK. See Unlocking Research at https://unlockingresearch.blog.lib.cam.ac.uk/. At LIBER 2017, in a session on Staff Education, there were discussions about the recruitment of 'non-librarians' into research libraries. It was suggested that there is a need for research librarians to be able to communicate core library skills, but that these skills might be easier to teach and learn 'on the job,' whereas other essential skills, such as communication, might be better found in people coming from sectors and educational backgrounds other than librarianship. See Warren (2017).

${ }^{2}$ Vitae is the national organisation that champions researcher development on behalf of the Research Councils in the UK.
\end{abstract}
${ }^{3}$ Also see: Alpay and Walsh (2008); Bray and Boon (2011).
${ }^{4}$ The report was based on data from year one of a planned three-year qualitative study, using personal interviews with 116 Early Career Researchers from seven countries: UK, US, China, France, Spain, Poland, and Malaysia (CIBER, 2016).

${ }^{5}$ In August 2013, the Association of Research Libraries (ARL), the Canadian Association of Research Libraries (CARL), the Association of European Research Libraries (LIBER), and the Confederation of Open Access Repositories (COAR), launched the joint Task Force on Librarians' Competencies in Support of E-Research and Scholarly Communication (Schmidt et al., 2016).

${ }^{6}$ https://www.clir.org/fellowships/postdoc/.

${ }^{7}$ A term used by Jaguszewski and Williams (2013, p. 7).

${ }^{8}$ Of these $70 \%$ are at postgraduate masters' level, and 22\% have a Diploma. One respondent has a postgraduate diploma, and another respondent is working towards an MLitt. No respondents indicated that they have a bachelors' degree in LIS or Archives.

${ }^{9}$ These postgraduate qualifications are almost exclusively in Arts and Humanities fields (in 11 out of 12 cases).

${ }^{10}$ The respondent who had a PhD and a LIS/archive qualification answered the questions represented by Figures $2-4$ only in relation to their LIS/Archive qualification, and did not also complete the same questions in relation to their PhD. Therefore, the number of respondents with PhDs represented by the data in Figures $2-4$ is six. Of those respondents with $\mathrm{PhDs}, 29 \%$ completed their doctoral degrees less than five years ago, and $43 \%$ completed between six and ten years ago. 
${ }^{11}$ Phrase used by Kingsley (2016b).

${ }^{12}$ For the purpose of limiting the overall length of the survey, in order to encourage survey completion by as many respondents as possible, only 27 out of the RDF's 63 descriptors were listed. Selection was based upon those descriptors which have most overlap with and relevance to library work. Descriptors that are either very general e.g. equality and diversity, health and safety, and ethics, or are very specific to research e.g. research strategy, were not included in the survey list. Nevertheless, following the results of this survey, employing the full list of Researcher Development Framework descriptors in future evaluations of librarians' skills is seen as potentially valuable.

${ }^{13}$ See Steven (2011). 